\title{
ANGIOTENSIN II TYPE 1 RECEPTOR MEDIATES CELL PROLIFERATION VIA PROTEIN TYROSINE KINASE AND VOLTAGE-DEPENDENT CALCIUM CHANNELS
}

\author{
Yasuhiro Ozawa ${ }^{1}$, Yasuyuki Suzuki ${ }^{1}$, Kazuo Murakami $^{1}$ and Hitoshi Mryazaki ${ }^{1,2}$ \\ 'Institute of Applied Biochemistry, Gene Experiment Center, and Center for Tsukuba Advanced Research Alliance, University of \\ Tsukuba, Ibaraki 305-0006, Japan
}

\begin{abstract}
Here we examined the signaling pathway mediated by angiotensin II (Ang II) type 1 receptor $\left(\mathrm{AT}_{1}\right)$ leading to Ang II-induced proliferation of PC12 cells stably expressing the recombinant $\mathrm{AT}_{1}$ receptor (PC12/rAT1). The cell number increased to 2.4-fold over the control 4 days after Ang II addition. Ang II-induced $\left[{ }^{3} \mathrm{H}\right]$ thymidine incorporation was affected neither by pertussis toxin nor by calphostin $\mathrm{C}$, a protein kinase $\mathrm{C}$ (PKC) inhibitor. In contrast, the Ang II effect was almost completely inhibited by the protein tyrosine kinase (PTK) inhibitor genistein. In addition, tyrphostin AG1478, an epidermal growth factor (EGF) receptor-selective inhibitor, significantly inhibited Ang II-induced $\left[{ }^{3} \mathrm{H}\right]$ thymidine incorporation but had no effect on the basic fibroblast growth factor action. Nicardipine, an L-type $\mathrm{Ca}^{2+}$ channel blocker, also inhibited the Ang II function. Together, these data demonstrate that $\mathrm{Gi}$ proteins and $\mathrm{PKC}$ are not involved in Ang II-induced cell proliferation of $\mathrm{PC} 12 / \mathrm{rAT} 1$ cells through the $\mathrm{AT}_{1}$ receptor, and that $\mathrm{Ca}^{2+}$ influx through voltage-dependent $\mathrm{Ca}^{2+}$ channels and activation of PTK(s) are critical for this process. Furthermore, our data suggest that ligand-independent activation of a receptor tyrosine kinase(s), called transactivation, plays an important role in $\mathrm{AT}_{1}$-mediated cell proliferation through $\mathrm{Gq}$ proteins.
\end{abstract}

Angiotensin II (Ang II) is the major effector molecule of the renin-angiotensin system that helps to maintain fluid balance and blood pressure $(4,27)$. Two major subtypes of Ang II receptors have been identified based on pharmacological and molecular biological studies and designated $\mathrm{AT}_{1}$ and $\mathrm{AT}_{2}$, both of which belong to the superfamily of $\mathrm{G}$ pro-

Abbreviations: Ang II, angiotensin II; $\mathrm{AT}_{1}$, angiotensin II type 1 receptor; $\mathrm{AT}_{2}$, angiotensin II type 2 receptor; PKC, a protein kinase C; PTK, protein tyrosine kinase; EGF, epidermal growth factor; GPCR, G protein-coupled receptor; ET-1, endothelin-1; LPA, lysophosphatidic acid; MAPK, mitogen-activated protein kinase; PTX, pertussis toxin; IGF-1, insulin-like growth factor1; PDGF, platelet-derived growth factor

${ }^{2}$ Correspondence to: $\mathrm{H}$. Miyazaki at Gene Experiment Center, University of Tsukuba, Ibaraki 305-0006, Japan. Telefax: 81-298-53-6006; E-mail: hitomy1@sakura. cc.tsukuba.ac.jp tein-coupled receptors (GPCRs) $(15,22,24,32)$. The $\mathrm{AT}_{1}$ receptor is further separated into two subpopulations, termed $\mathrm{AT}_{1 \mathrm{~A}}$ and $\mathrm{AT}_{1 \mathrm{~B}}$, in rodents (14). Most of the well-known functions of Ang II are mediated by the $\mathrm{AT}_{1}$ receptor, whereas there is little information regarding the physiological roles of the $\mathrm{AT}_{2}$ receptor $(10,12,38,41)$.

Most recent studies of Ang II actions have focused upon its cell growth activity through the $\mathrm{AT}_{1}$ receptor in the pathogenesis of hypertension, cardiac hypertrophy, and atherosclerosis $(2,9,13$, $16,28,31)$. In addition to the $\mathrm{AT}_{1}$ receptor, it is known that many other GPCRs lead to cell proliferation $(21,34,37)$, although the intracellular mechanisms are still poorly characterized. PC12 pheochromocytoma cells are widely used for studying cell proliferation as well as differentiation and, apoptosis. Furthermore, adrenal chromaffin cells, the origin of PC12 cells, endogenously 
express the $\mathrm{AT}_{1}$ receptor, although the expression level is quite low in PC12 cells $(8,23)$. Therefore, we constructed $\mathrm{PC} 12$ cells stably expressing the rat recombinant $\mathrm{AT}_{1}$ receptor. These cells will provide a good model for elucidating the mechanism underlying cell proliferation mediated by the $\mathrm{AT}_{1}$ receptor.

To elucidate the intracellular mechanism of Ang II-induced proliferation, we examined the implication of $\mathrm{Gi}$ proteins, protein kinase $\mathrm{C}(\mathrm{PKC})$, protein tyrosine kinases (PTKs), and $\mathrm{Ca}^{2+}$ influx. Particularly, PTKs and $\mathrm{Ca}^{2+}$ influx are of our great interest. There is accumulating evidence that GPCRs, including the $\mathrm{AT}_{1}$ receptor, mediate the tyrosine phosphorylation of many intracellular proteins like growth factor receptors which possess intrinsic protein kinase activity $(11,20,33)$. Moreover, Daub et al. (6) have recently demonstrated that in Rat-1 fibroblast cells, the epidermal growth factor (EGF) receptor became tyrosine-phosphorylated and activated without its ligand by the GPCR agonists endothelin-1 (ET-1), lysophosphatidic acid (LPA), and thrombin by a process called transactivation and that this process was mainly responsible for mitogen-activated protein kinase (MAPK) activation by these agonists. These findings prompted us to investigate whether Ang II-elicited cell proliferation is mediated by PTKs including the EGF receptor. The contribution of extracellular $\mathrm{Ca}^{2+}$ influx to Ang II-stimulated cell proliferation also has not yet been clarified, although stimulation of the $\mathrm{AT}_{1}$ receptor induces $\mathrm{Ca}^{2+}$ influx across the plasma membrane as well as an increase in $\left[\mathrm{Ca}^{2+}\right]$ i derived from intracellular $\mathrm{Ca}^{2+}$ stores (26). Lev et al. (18) have demonstrated that extracellular $\mathrm{Ca}^{2+}$ influx induced the activation of the cytosolic PTK termed PYK2, which leads to MAPK activation, in PC12 cells. The EGF receptor was also found to become tyrosine-phosphorylated by the activation of L-type $\mathrm{Ca}^{2+}$ channels in PC12 cells (30). Therefore, extracellular $\mathrm{Ca}^{2+}$ influx may be important for Ang IIinduced cell proliferation in concert with PTKs.

In this study, after we confirmed an increase in cell number, we mainly examined the Ang IIinduced $\left[{ }^{3} \mathrm{H}\right]$ thymidine incorporation into DNA, rather than MAPK activity, to elucidate direct association of the intracellular signal components with cell proliferation.

\section{MATERIALS AND METHODS}

\author{
Materials \\ ${ }^{125} \mathrm{I}-\left[\mathrm{Sar}^{1}\right.$, Ile ${ }^{8}$ Ang II ( ${ }^{125}$ I-sarile) and [methyl-
}

$\left.{ }^{3} \mathrm{H}\right]$ thymidine were purchased from Amersham International plc (Bucks, U.K.). Angiotensin II, sarile, leupeptin, and antipain were obtained from the Peptide Institute (Osaka, Japan). DuP753 and PD123319 were kindly provided by $\mathrm{Dr} D$. R. Smith (Du Pont Merck Pharmaceutical, Wilmintone, DE) and Dr J. A. Keiser (WarnerLambert, Ann Abor, MI), respectively. Recombinant mouse basic fibroblast growth factor (bFGF) and EGF were from Toyobo (Tokyo, Japan). Calphostin $\mathrm{C}$ and genistein were from Wako (Osaka, Japan). Tyrphostin AG1478 was obtained from Calbiochem. The eukaryotic expression vector pCDNA3-neo was from Invitrogen (San Diego, CA). Nicardipine was from Sigma.

\section{Cell Culture and Construction of PC12/rAT1 \\ Cell Line Stably Expressing the Rat $A T_{I A}$ Receptor}

PC12 cells were maintained in DMEM supplemented with $10 \%$ fetal calf serum (FCS) and 5\% horse serum. Cells were cultured on $100-\mathrm{mm}$ dishes at $37^{\circ} \mathrm{C}$ in $5 \% \mathrm{CO}_{2}, 95 \%$ air. A $2.2-\mathrm{kb}$ fragment containing the entire cording sequence for the rat $\mathrm{AT}_{1 \mathrm{~A}}$ receptor was inserted into the Hind III/Xba I sites of the eukaryotic expression vector pCDNA3neo and this construction was stably introduced into PC12 cells using electroporation. Briefly, cells were washed twice with phosphate-buffered saline (PBS) and resuspended in PBS at a density of $1 \times$ $10^{7}$ cells $/ \mathrm{ml}$. Cell suspension $(1 \mathrm{ml})$ containing 20 $\mu \mathrm{g}$ plasmid DNA was transferred into an electroporation cuvette and the cells were shocked $(960 \mu \mathrm{F}$, $250 \mathrm{~V})$. Stable transfectants were selected in medium containing $800 \mu \mathrm{g} / \mathrm{ml}$ of $\mathrm{G} 418$. One of the transfectants, named PC12/rAT1 cells, was used in this study.

\section{Competitive Binding Study}

For competitive binding studies, cells in 24-well plastic dishes were washed twice with $0.5 \mathrm{ml}$ of ice-cold buffer A consisting of HBSS (in $\mathrm{mM}$ : $\mathrm{NaCl}, 138 ; \mathrm{KCl}, 5.0 ; \mathrm{KH}_{2} \mathrm{PO}_{4}, 0.3 ; \mathrm{Na}_{2} \mathrm{HPO}_{4}, 0.3$; $\mathrm{MgSO}_{4}, 0.8 ; \mathrm{CaCl}_{2}, 1.3$; and $\mathrm{NaHCO}_{3}, 4.0$ ) buffered with $20 \mathrm{mM}$ 2-[4-(2-hydroxyethyl)-1-piperazinyl]ethanesulfonic acid (Hepes), $\mathrm{pH} 7.4$, and incubated with $50 \mathrm{pM}{ }^{125}$ I-sarile in the presence of increasing concentrations of unlabeled sarile in $200 \mu \mathrm{l}$ of HBSS containing $0.1 \%$ crystallized bovine serum albumin, $50 \mu \mathrm{g} / \mathrm{ml}$ leupeptin, $25 \mu \mathrm{g} / \mathrm{ml}$ antipain, and $1 \mathrm{mM}$ phenylmethylsulfonyl fluoride at $25^{\circ} \mathrm{C}$ 
for $2 \mathrm{~h}$. Thereafter, cells were washed twice with $0.5 \mathrm{ml}$ of buffer A, solubilized with $1 \mathrm{~N} \mathrm{NaOH}$, then the radioactivity was counted.

\section{Mitogenic Assays}

Cells were seeded at a density of $5 \times 10^{5}$ cells/well in 6-well plates for the cell proliferation assay and $5 \times 10^{4}$ cells/well in 24-well plates for the $\left[{ }^{3} \mathrm{H}\right]$ thymidine incorporation assay. Cells were cultured for $24 \mathrm{~h}$ in DMEM supplemented with $10 \%$ FCS and 5\% horse serum, washed with serum-free DMEM, and incubated for an additional $48 \mathrm{~h}$. Cell were counted using a hemocytemeter after the indicated periods of Ang II stimulation. To assay $\left[{ }^{3} \mathrm{H}\right]$ thymidine incorporation, cells were exposed to various stimuli for $24 \mathrm{~h}$, then labeled with $0.5 \mu \mathrm{Ci}$ of $\left[{ }^{3} \mathrm{H}\right]$ thymidine for an additional $2 \mathrm{~h}$. Thereafter, the cells were washed once with cold PBS and incubated with $5 \%$ trichloroacetic acid for $2 \mathrm{~h}$ at $4^{\circ} \mathrm{C}$. The fixed cells were rinsed with cold $5 \%$ trichloroacetic acid, incubated for $2 \mathrm{~h}$ with $1 \mathrm{~N}$ $\mathrm{NaOH}$ at $37^{\circ} \mathrm{C}$, then counted using a liquid scintillation counter.

\section{RESULTS}

\section{Biochemical Properties of the Expressed Rat $A T_{1}$ Receptor}

We constructed PC12 cell lines stably expressing the rat $\mathrm{AT}_{1}$ receptor (PC12/rAT1). To assess biochemical characteristics of the $\mathrm{AT}_{1}$ receptor expressed in PC12/rAT1 cells, competition binding experiments were performed. As shown in Fig. 1, the binding of ${ }^{125} \mathrm{I}$-sarile, a subtype-nonselective Ang II receptor antagonist, to the cells was dosedependently inhibited by unlabeled sarile. In contrast, the radioligand binding to untransfected PC12 cells was not observed (data not shown). Scatchard plots transformed from the competition curve revealed binding parameters with a dissociation constant $(\mathrm{Kd})$ of $450 \mathrm{pM}$ and a binding site number (Bmax) of $7.4 \times 10^{4}$ sites/cell, the $\mathrm{Kd}$ value being in good agreement with those of previous reports $(4,26,35)$.

\section{Ang II Stimulates Cell Proliferation}

As shown in Fig. 2, Ang II $(1 \mu \mathrm{M})$ induced a 1.6and 2.4-fold increase in the cell number for $48 \mathrm{~h}$ and $96 \mathrm{~h}$, respectively, compared with the vehicle control. In contrast, non-transfected PC12 cells did not respond to Ang II treatment (data not shown).

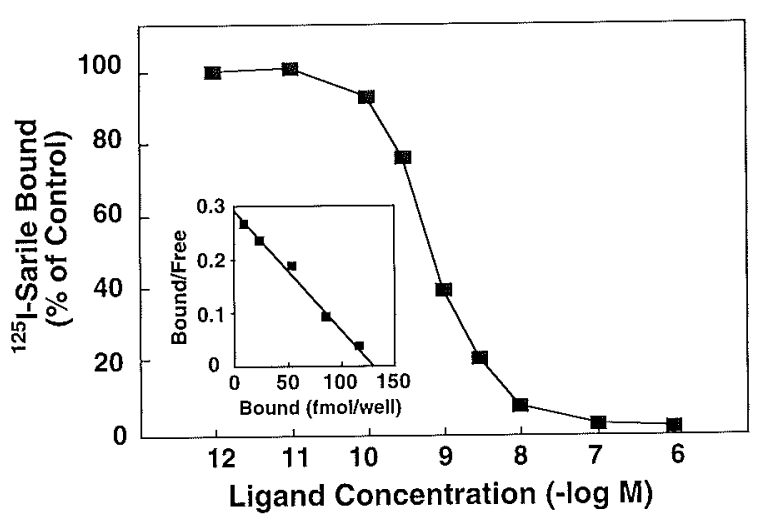

Fig. 1 Binding of ${ }^{125}$ I-sarile to PC12/rAT1 cells. Cells were incubated with $50 \mathrm{pM}^{125} \mathrm{I}$-sarile in the presence of the indicated concentrations of unlabeled sarile. Inset, Scatchard-plot analysis of ${ }^{125} \mathrm{I}$-sarile binding. Scatchard plots were transformed from the competition curve of sarile. The curve shown is a representative of two separate experiments performed in duplicate.

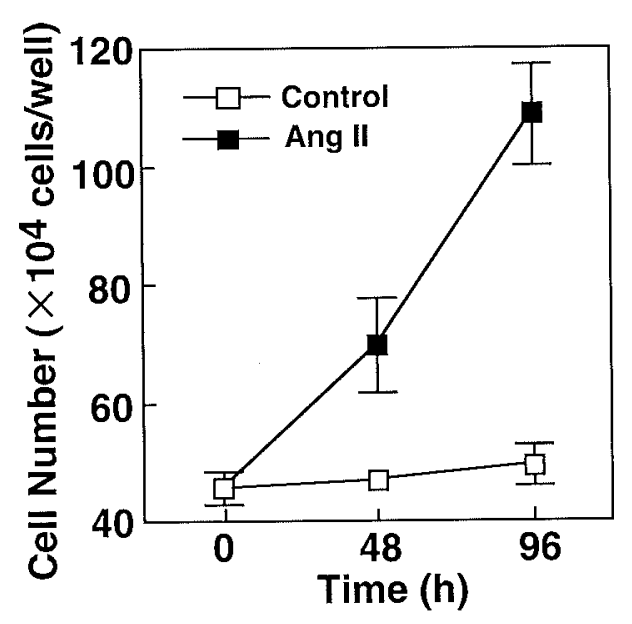

Fig. 2 Effect of Ang II on PC12/rAT1 cell proliferation. Cells were incubated with Ang II $(1 \mu \mathrm{M})$ for 48 and $96 \mathrm{~h}$. The data represent the means $\pm S E$ of three separate experiments performed in triplicate.

Ang II Stimulates $\left[^{3} \mathrm{H}\right]$ Thymidine Incorporation via the $A T_{1}$ Receptor

We determined whether or not Ang II stimulates DNA synthesis by means of a $\left[{ }^{3} \mathrm{H}\right]$ thymidine incorporation assay. Fig. 3 shows that Ang II $(1 \mu \mathrm{M})$ induced a 3.1 -fold increase in $\left[{ }^{3} \mathrm{H}\right]$ thymidine incorporation compared with the vehicle control. To confirm that this Ang II effect was mediated by the $\mathrm{AT}_{1}$ receptor, the cells were incubated with the $\mathrm{AT}_{1}$ 


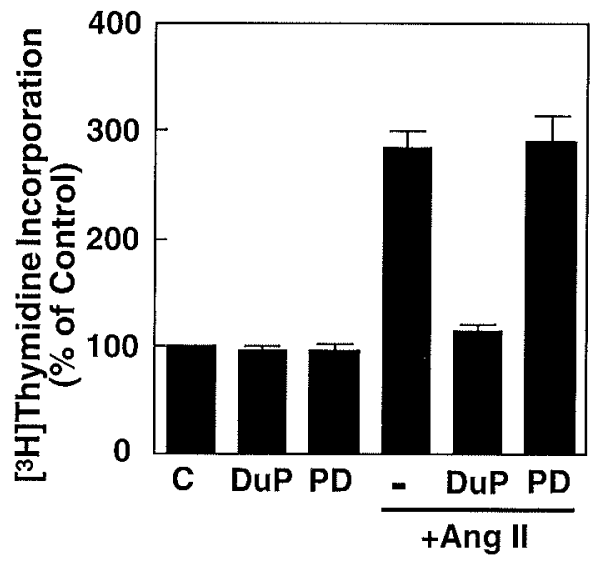

Fig. 3 Effect of Ang II receptor antagonists on Ang IIstimulated $\left[{ }^{3} \mathrm{H}\right]$ thymidine incorporation in PC12/rAT1 cells. Cells were incubated with Ang II $(1 \mu \mathrm{M})$ in the presence and absence of DuP753 $(50 \mu \mathrm{M})$ or PD123319 $(50 \mu \mathrm{M})$ for $24 \mathrm{~h}$, and $\left[{ }^{3} \mathrm{H}\right]$ thymidine incorporation was determined. Results are expressed as a percentage of the control value that indicates $\left[{ }^{3} \mathrm{H}\right]$ thymidine incorporation in the absence of stimuli. The data represent the means $\pm \mathrm{SE}$ of three separate experiments performed in triplicate. The control value of $\left[{ }^{3} \mathrm{H}\right]$ thymidine incorporation was $5,200 \mathrm{cpm} \pm 200 \mathrm{cpm} /$ well. C, control; DuP, DuP 753; PD, PD123319

receptor- and the $\mathrm{AT}_{2}$ receptor-selective antagonists, DuP753 $(50 \mu \mathrm{M})$ and PD123319 $(50 \mu \mathrm{M})$, respectively, in the presence or absence of Ang II $(1 \mu \mathrm{M})$. DuP753 completely blocked $\left[{ }^{3} \mathrm{H}\right]$ thymidine incorporation induced by Ang II, whereas PD123319 had no effect. Together with the data shown in Fig. 2, these results demonstrate that Ang II stimulates DNA synthesis followed by cell proliferation via the $\mathrm{AT}_{\mathrm{i}}$ receptor in PC12/rAT1 cells.

\section{Effect of Pertussis Toxin on Ang II-Induced $\left[{ }^{3} H\right]$ Thymidine Incorporation}

The $\mathrm{AT}_{1}$ receptor is linked to $\mathrm{Gq}$ - and Gi-proteins $(4,26,35)$. To examine the role of Gi-mediated pathways in Ang II-induced DNA synthesis, the cells were pretreated with pertussis toxin (PTX, $200 \mathrm{ng} / \mathrm{ml}$ ) for $24 \mathrm{~h}$. PTX failed to inhibit Ang II (1 $\mu \mathrm{M}$ )-induced $\left[{ }^{3} \mathrm{H}\right]$ thymidine incorporation, as indicated in Fig. 4A. In contrast, LPA $(10 \mu \mathrm{M})$-stimulated $\left[{ }^{3} \mathrm{H}\right]$ thymidine incorporation was inhibited by approximately $65 \%$ by PTX. LPA is known to stimulate Gi-proteins and inhibit adenylyl cyclase activities in PC12 cells (39). Therefore, Gq- but not Gi-proteins are presumably responsible for Ang II-induced DNA synthesis in these cells.
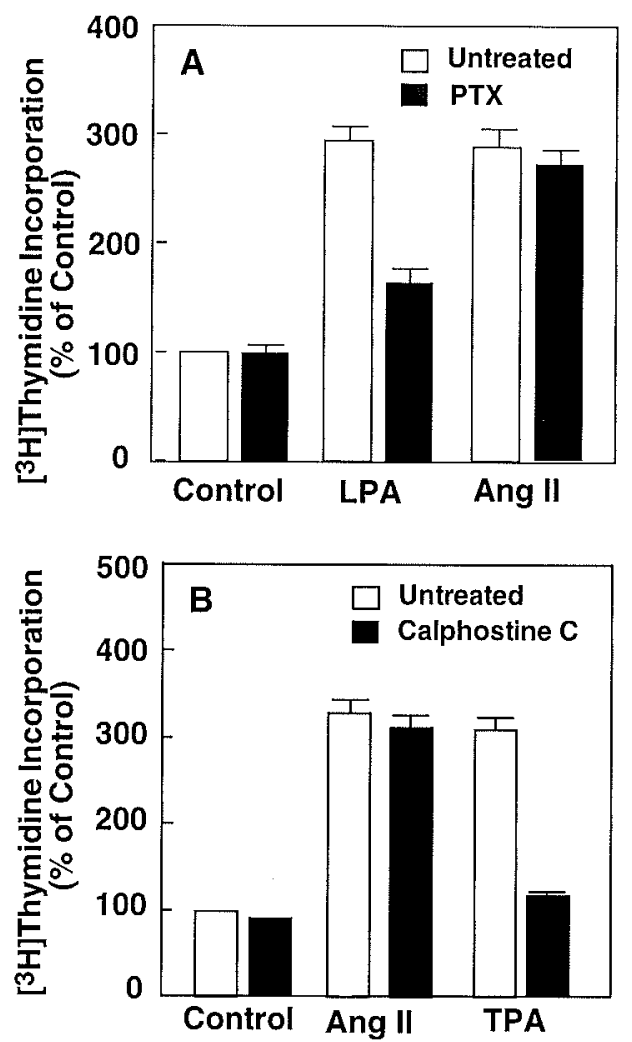

Fig. 4 Effect of PTX and calphostin C on Ang IIstimulated $\left[{ }^{3} \mathrm{H}\right]$ thymidine incorporation in PC12/rAT1 cells. (A) Cells were stimulated with Ang II $(1 \mu \mathrm{M})$ and LPA $(10 \mu \mathrm{M})$ for $24 \mathrm{~h}$ after a $24-\mathrm{h}$ preincubation in the presence or absence of PTX $(200 \mathrm{ng} / \mathrm{ml})$, then $\left[{ }^{3} \mathrm{H}\right]$ thymidine incorporation was determined. Results are expressed as a percentage of the control value obtained in the absence of stimuli and PTX pretreatment. The data represent the means $\pm \mathrm{SE}$ of three separate experiments performed in triplicate. (B) Cells were stimulated with Ang II $(1 \mu \mathrm{M})$ and TPA $(100 \mathrm{nM})$ with or without calphostin $\mathrm{C}(100 \mathrm{nM})$ for $24 \mathrm{~h}$, respectively, then $\left[{ }^{3} \mathrm{H}\right]$ thymidine incorporation was determined. Results are expressed as a percentage of the control value obtained in the absence of stimuli. The data represent the means $\pm S E$ of three separate experiments performed in triplicate.

\section{Effect of Calphositin C on Ang II-Induced $\left[{ }^{3} H\right]$ Thymidine Incorporation}

Stimulation of the $\mathrm{AT}_{1}$ receptor leads to phospholipase $\mathrm{C}$ (PLC) activation, resulting in the generation of inositol trisphosphate $\left(\mathrm{IP}_{3}\right)$ and diacylglycerol, with subsequent $\mathrm{Ca}^{2+}$ mobilization and PKC activation, respectively $(4,24,26,32,35)$. PKC has been reported to be involved in the Ang II-induced 
mitogenic response in some cells including adrenal glomerulosa cells and cardiac fibroblasts $(25,42)$. Therefore, to study whether or not the PKC pathway is responsible for Ang II-induced DNA synthesis, the cells were incubated with calphostin $\mathrm{C}$ (100 nM), a PKC-selective inhibitor. Calphostin C had no effect on subsequent Ang II $(1 \mu \mathrm{M})$-induced $\left[{ }^{3} \mathrm{H}\right]$ thymidine incorporation as shown in Fig. 4B. Basal incorporation was also unaffected by this inhibitor. In contrast, induction of $\left[{ }^{3} \mathrm{H}\right]$ thymidine incorporation by $100 \mu \mathrm{M} 12-O$-tetradecanoyl phorbol-13-acetate (TPA), a direct activator of PKC, was completely inhibited by calphostin C. These results demonstrate that DNA synthesis induced by Ang II does not require the PKC pathway in these cells.

\section{Effect of Genistein on Ang II-Induced $\left[{ }^{3} H\right]$ Thymidine Incorporation}

Previous studies have revealed that Ang II rapidly stimulates the tyrosine phosphorylation of cellular proteins through the $\mathrm{AT}_{1}$ receptor and this phosphorylation is blocked by the tyrosine kinase inhibitor genistein in several cell types, including vascular smooth muscle cells (VSMCs) and cardiac fibroblasts $(4,11,20,33)$. However, it is not clear whether this Ang II effect is associated with its mitogenic effect. Therefore, we examined the involvement of the PTK pathway in Ang IIinduced DNA synthesis by using genistein. As shown in Fig. 5A, genistein dose-dependently inhibited Ang II $(1 \mu \mathrm{M})$-stimulated $\left[{ }^{3} \mathrm{H}\right]$ thymidine incorporation with an $\mathrm{IC}_{50}$ value of $80 \mu \mathrm{M}$, indicating that PTK activation is essential for DNA synthesis induced by Ang II. Genistein even at 100 $\mu \mathrm{M}$ did not act as a nonspecific cytotoxin, as it did not affect cell viability for $24 \mathrm{~h}$ after addition (data not shown). Therefore, $\operatorname{PTK}(\mathrm{s})$ is thought to be responsible for Ang II-stimulated DNA synthesis.

\section{Effect of Tyrphostin AG1478 on Ang II-} Induced $\left[{ }^{3} H\right]$ Thymidine Incorporation

To know the implication of EGF receptor transactivation in Ang II-induced DNA synthesis, we assessed the effect of tyrphostin AG1478, an EGF receptor-specific inhibitor, on the Ang II action. As shown in Fig. 5B, addition of AG1478 (500 nM) reduced Ang II-stimulated $\left[{ }^{3} \mathrm{H}\right]$ thymidine incorporation by $30 \%$ and completely blocked the EGF $(100 \mathrm{ng} / \mathrm{ml})$ action. In contrast, $\left[{ }^{3} \mathrm{H}\right]$ thymidine incorporation mediated by bFGF receptors, which
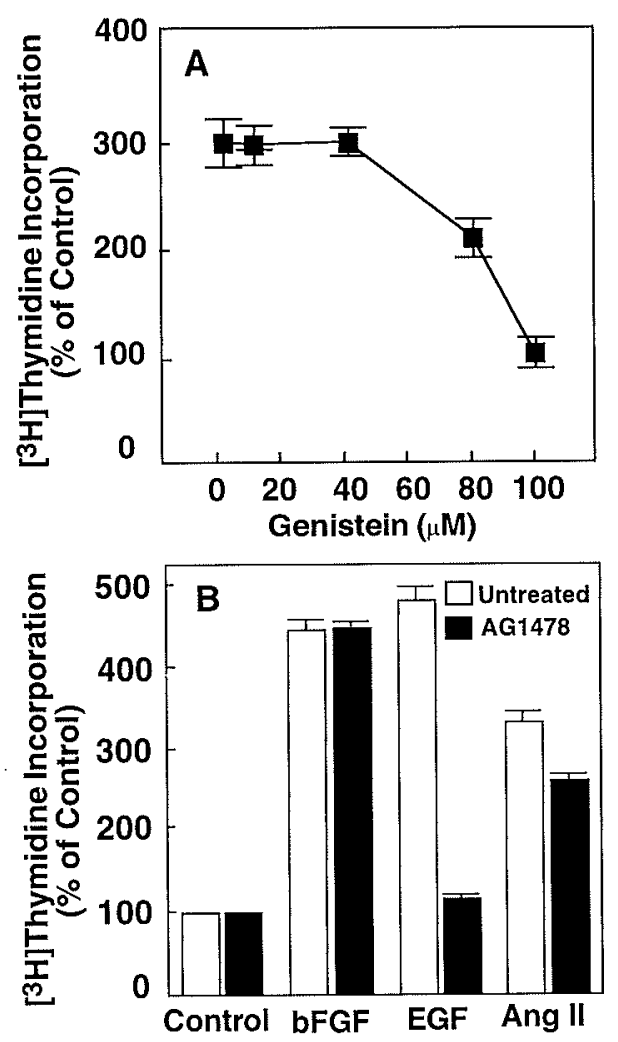

Fig. 5 Effect of genistein and tyrphostin AG1478 on Ang II-stimulated $\left[{ }^{3} \mathrm{H}\right]$ thymidine incorporation in PC12/rAT1 cells. (A) Cells were stimulated with Ang II $(1 \mu \mathrm{M})$ in the presence of various concentrations of genistein for $24 \mathrm{~h}$, then $\left[{ }^{3} \mathrm{H}\right]$ thymidine incorporation was determined. Results are expressed as a percentage of the control value obtained in the absence of stimuli. The data represent the means $\pm \mathrm{SE}$ of three separate experiments performed in triplicate. (B) Cells were stimulated with Ang II $(1 \mu \mathrm{M})$, bFGF $(20 \mathrm{ng} / \mathrm{ml})$, and EGF $(100$ $\mathrm{ng} / \mathrm{ml}$ ) in the presence or absence of tyrphostin AG1478 $(500 \mathrm{nM})$ for $24 \mathrm{~h}$, respectively, then $\left[{ }^{3} \mathrm{H}\right]$ thymidine incorporation was determined. Results are expressed as a percentage of the control value obtained in the absence of stimuli. The data represent the means \pm SE of three separate experiments performed in triplicate.

possess an intrinsic PTK activity as the EGF receptor, was not affected by this inhibitor. Therefore, the transactivation mechanism of EGF receptor is involved in part in Ang II-elicited DNA synthesis of these cells.

\section{Effect of Nicardipine on Ang II-Induced $[3$ H]Thymidine Incorporation}

An increase in $\left[\mathrm{Ca}^{2+}\right] \mathrm{i}$ is important for Ang II actions mediated by the $\mathrm{AT}_{1}$ receptor such as 
smooth muscle contraction and aldosterone secretion $(3-5,27)$. The $\left[\mathrm{Ca}^{2+}\right] \mathrm{i}$ response to Ang II is characterized by an initial transient peak due to intracellular $\mathrm{Ca}^{2+}$ mobilization, followed by a sustained plateau phase that is dependent on $\mathrm{Ca}^{2+}$ entry across the plasma membrane via $\mathrm{Ca}^{2+}$ channels $(4,26)$. Since L-type calcium channels are expressed in PC12 cells (29), we examined the effect of nicardipine, an L-type calcium channel blocker, on DNA synthesis stimulated by Ang II and bFGF. Nicardipine (100 $\mathrm{nM}$ ) reduced Ang II (1 $\mu \mathrm{M})$-induced $\left[{ }^{3} \mathrm{H}\right]$ thymidine incorporation by $87 \%$, whereas it had no significant effect on the bFGF $(20 \mathrm{ng} / \mathrm{ml})$ action, as indicated in Fig. 6. Nicardipine $(100 \mathrm{nM})$ did not act as a nonspecific cytotoxin under our experimental conditions because it did not affect basal $\left[{ }^{3} \mathrm{H}\right]$ thymidine incorporation and the response to bFGF. These suggest that $\mathrm{Ca}^{2+}$ influx through L-type $\mathrm{Ca}^{2+}$ channels contributes to DNA synthesis induced by Ang II but not by bFGF.

\section{DISCUSSION}

The $\mathrm{AT}_{1}$ receptor-mediated DNA synthesis was blocked by the PTK inhibitor genistein in PC12/rAT1 cells. Also, the EGF receptor-specific inhibitor AG1478 reduced the Ang II action by $30 \%$, suggesting that transactivation of the EGF receptor contributes to cell proliferation mediated by the $\mathrm{AT}_{1}$ receptor in these cells. The incomplete inhibition of the $\mathrm{AT}_{1}$ receptor function by $\mathrm{AG} 1478$ may in part result from the involvement of transactivation of other receptor tyrosine kinase(s) such as bFGF receptors and insulin-like growth factor-1 (IGF-1) receptors. In fact, it was demonstrated that Ang II-induced tyrosine phosphorylation of platelet-derived growth factor (PDGF) receptors and IGF-1 receptors was observed in VSMCs (1, 19). However, PDGF receptors are not implicated at least in PC12/rAT1 cells because these cells do not express PDGF receptors (data not shown). In addition to this view, two other explanations are possible for the incomplete inhibition by AG1478. The first is that activation of the $\mathrm{AT}_{1}$ receptor may produce secondary proliferative stimuli. The second is that PTK(s) other than growth factor receptors may be involved because Daub et al. (6) revealed that GPCR agonist-induced tyrosine phosphorylation of focal adhesion kinase and paxillin was unaffected by AG1478.

Recently, $\mathrm{Ca}^{2+}$-dependent PTK has been cloned from a human brain cDNA library and termed

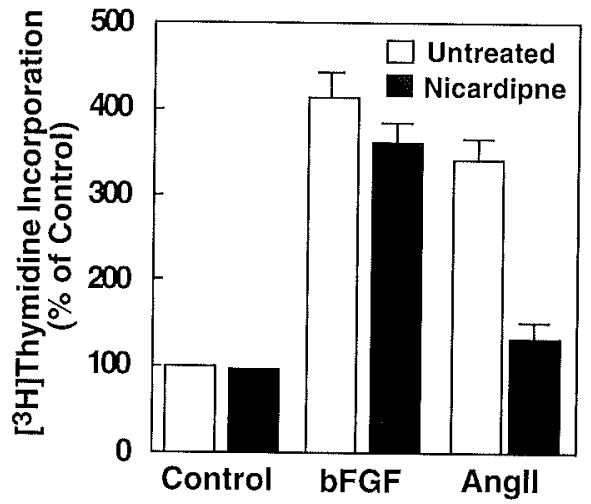

Fig. 6 Effect of nicardipine on Ang II-stimulated $\left[{ }^{3} \mathrm{H}\right]$ thymidine incorporation in PC12/rAT 1 cells. Cells were stimulated with Ang II $(1 \mu \mathrm{M})$ and bFGF $(20$ $\mathrm{ng} / \mathrm{ml})$ in the presence or absence of nicardipine (100 $\mathrm{nM}$ ) for $24 \mathrm{~h}$, respectively, then $\left[{ }^{3} \mathrm{H}\right]$ thymidine incorporation was determined. Results are expressed as a percentage of the control value obtained in the absence of stimuli. The data represent the means \pm SE of three separate experiments performed in triplicate.

PYK2 (18). PYK2 was found to be expressed at high levels in PC12 cells and to be activated by Gq-protein-coupled receptors and by the stimuli leading to extracellular $\mathrm{Ca}^{2+}$ influx but not by calmodulin. Our data also revealed that extracellular $\mathrm{Ca}^{2+}$ influx is critical for the $\mathrm{AT}_{1}$ receptor function as well as PTK(s). Moreover, in PC12/rAT1 cells, L-type $\mathrm{Ca}^{2+}$ channels were involved because nicardipine, specific for this type of channels, inhibited the Ang II action at a low concentration $(100 \mathrm{nM})$. In fact, the sustained phase of Ang IIevoked increase in $\left[\mathrm{Ca}^{2+}\right] \mathrm{i}$, which results from extracellular $\mathrm{Ca}^{2+}$ influx, was significantly attenuated by $100 \mathrm{nM}$ nicardipine in these cells (data not shown). Therefore, PYK2 is one of the candidates for the PTK(s) implicated in the $\mathrm{Ca}^{2+} / \mathrm{PTK}$ pathway that is responsible for the $\mathrm{AT}_{1}$ receptor-mediated proliferation. On the other hand, Eguchi et al. (7) have recently indicated that $\mathrm{Ca}^{2+}$ influx was not required for MAPK activation in response to Ang II in rat VSMCs. These findings suggest that different PTK(s) may contribute in a cell-specific way to GPCR-mediated cell proliferation.

The finding that MAPK activation by GPCR agonists is mediated by $\beta \gamma$ subunits of Gi-proteins is one of the recent highlights among GPCRinduced events (40). For example, Gi-protein-coupled receptors including $\alpha_{2 \mathrm{~A}}$-adrenergic, LPA, and thrombin receptors stimulate MAPK activation (39). In contrast, this study indicates that Gi-pro- 
teins are not implicated in Ang II-induced cell proliferation and that only $\mathrm{Gq}$-proteins are responsible for this Ang II effect in PC12/rAT1 cells as they are for other functions of Ang II. Eguchi et al. (7) also have recently indicated that Gq proteins but not $\mathrm{Gi}$ proteins contribute to MAPK activation mediated by the $\mathrm{AT}_{1}$ receptor.

PC12 cells are widely used for investigating catecholamine secretion and cell differentiation in addition to cell proliferation. Ang II is known to secrete catecholamines via the $\mathrm{AT}_{1}$ receptor from adrenal chromaffin cells, the origin of PC12 cells, although the mechanism remains unclear (36). Laflamme et al. (17) reported that the $\mathrm{AT}_{2}$ receptor mediates neuronal differentiation, whereas the $\mathrm{AT}_{1}$ receptor mediates the inhibition of the differentiation, using nondifferentiated and dibutyryl cAMPinduced differentiated NG108-15 cells. Therefore, PC12/rAT1 cells provide a useful model for examining the contribution of transactivation of the EGF receptor to these $\mathrm{AT}_{1}$ receptor functions.

In summary, this study demonstrates that Gi-proteins and PKC are not involved in Ang II-induced cell proliferation of PC12/rAT1 cells via the $\mathrm{AT}_{1}$ receptor and that $\mathrm{Ca}^{2+}$ influx through voltagedependent $\mathrm{Ca}^{2+}$ channels and the activation of PTK(s) are critical for this process. Furthermore, ligand-independent activation of a receptor tyrosine kinase(s), called transactivation, is required for a full proliferative response mediated by the $\mathrm{AT}_{1}$ receptor through $\mathrm{Gq}$ proteins.

We thank Ms Norma Foster for her help in preparing the manuscript. This work was supported in part by research grants from the Tsukuba Advanced Research Alliance in the University of Tsukuba.

Received 14 October 1997; and accepted 10 November 1997

\section{REFERENCES}

1. Ali M. S., Schieffer B., Delafonataine P., Bernstein K. E., Ling B. N. and Marrero M. B. (1997) Angiotensin II stimulates tyrosine phosphorylation and activation of insulin receptor substrate 1 and protein-tyrosine phosphatase 1D in vascular smooth muscle cells. J. Biol. Chem. 272, 12373-12379

2. Bader M., Wagner J., Lee M. and Ganten D. (1994) The role of the renin-angiotensin system in cardiovascular disease. Hypertension 17, 1-16

3. Bodart V., Ong H. and De Lean A. (1995) A role for protein tyrosine kinase in the steroidogenic pathway of angiotensin II in bovine zona glomerulosa cells. J. Steroid Biochem. Mol. Biol. 54, 55-62

4. Bottari S. P., de Jasparo M., Steckelings U. M. and
LEVENS N. R. (1993) Angiotensin II receptor subtypes: characterization, signaling mechanisms, and possible physiological implications. Front. Netroendocrinol. 14, 123-171

5. Burnay M. M., Python C. P., Vallotton M. B., Capponi A. M. and Rossier M. F. (1994) Role of the capacitative calcium influx in the activation of steroidogenesis by angiotensin-II in adrenal glomerulosa cells. Endocrinology 135, 751-758

6. Daub H., Weiss F. U., Wallasch C. and Ullrich A. (1996) Role of transactivation of the EGF receptor in signaling by G-protein-coupled receptors. Nature 379, 557-560

7. Eguchi S., Matsumoto T., Motley E. D., Utsunomiya H. and INAGAmi T. (1996) Identification of an essential signaling cascade for mitogen-activated protein kinase activation by angiotensin II in cultured rat vascular smooth muscle cells. J. Biol. Chem. 271, 14169-14175

8. Gasc J. M., Shanmugam S., Sibony M. and Corvol P. (1994) Tissue-specific expression of type 1 angiotensin II receptor subtypes. Hypertension 24, 531-537

9. Gibbons G. H., Pratt R. E. and Dzau V. J. (1992) Vascular smooth muscle cell hypertrophy vs. hyperplasia. J. Clin. Imest. 90, 456-461

10. Hein L., Barsh G. S., Pratt R. E., Dzau V. J. and KoBiLKA B. K. (1995) Behavioral and cardiovascular effects of disrupting the angiotensin II type-2 receptor gene in mice. Nature 377, 744-747

11. Huckle W. R., Dy R. C. and Earp H. S. (1992) Calciumdependent increase in tyrosine kinase activity stimulated by angiotensin II. Proc. Natl. Acad. Sci. USA 89, 8837-8841

12. Ichiki T., Labosky P. A., Shiota C., Okuyama S., Imagawa Y., Fogo A., Nimura F., Ichikawa I., Hogan B. L. M. and InAGami T. (1995) Effects on blood pressure and exploratory behavior of mice lacking angiotensin II type-2 receptor. Nature 377, 748-750

13. Itoh H., Mukoyama M., Pratt R. E., Gibbons G. H and Dzau V. J. (1993) Multiple autocrine growth factors modulate vascular smooth muscle cell growth response to angiotensin II. J. Clin. Invest. 91, 2268-2274

14. IWAI N. and INAGami T. (1992) Identification of two subtypes in the rat type I angiotensin II receptor. FEBS Lett. 298, 257-260

15. Kambayashi Y., Bardhan S., Takahashi K., Tsuzuki S., Inui H., Hamakubo T. and Inagami T. (1993) Molecular cloning of a novel angiotensin II receptor isoform involved in phosphotyrosine phosphatase inhibition. J. Biol. Chem. 268, 24543-24546

16. Kromer E. P. and Riegger G. A. J. (1988) Effects of longterm angiotensin converting enzyme inhibition on myocardial hypertrophy in experimental aortic stenosis in the rat. Amer: J. Cardiol. 62, 161-163

17. Laflamme L., Gasparo M., Gallo J. M., Payet M. D. and Gallo-Payet N. (1996) Angiotensin II induction of neurite outgrowth by $\mathrm{AT}_{2}$ receptors in NG108-15 cells. $J$. Biol. Chem. 271, 22729-22735

18. Lev S., Moreno H., Martinez R., Canoll P., Peles E., Musacchio J. M., Plowman G. D., Rudy B. and SChlessinger J. (1995) Protein tyrosine kinase PYK2 involved in $\mathrm{Ca}^{2+}$-induced regulation of ion channel and MAP kinase functions. Nature 376, 737-745

19. Linseman D. A., Benjamin C. W. and Jones D. A. (1995) Convergence of angiotensin II and platelet-derived growth factor receptor signaling cascades in vascular smooth muscle cells. J. Biol. Chem. 270, 12563-12568 
20. Marrero M. B., Paxton W. G., Duff J. L., Berk B. C. and BERNSTEIN K. E. (1994) Angiotensin II stimulates tyrosine phosphorylation of phospholipase $\mathrm{C}_{-{ }_{\gamma 1}}$ in vascular smooth muscle cells. J. Biol. Chem. 269, 10935-10939

21. MoolenaAR W. H. (1995) Lysophosphatidic acid, a multifunctional phospholipid messenger. J. Biol. Chem. 270, 12949-12952

22. Mukoyama M., Nakajima M., Horiuchi M., SaSamura H., Pratt R. E. and Dzau V. J. (1993) Expression cloning of type 2 angiotensin II receptor reveals a unique class of seven-transmembrane receptors. J. Biol. Chem. 268, 24539-24542

23. Murasawa S., Matsubara H., Urakami M. and Inada M. (1993) Regulatory elements that mediate expression of the gene for the angiotensin II type la receptor for the rat. $J$. Biol. Chem. 268, 26996-27003

24. Murphy T. J., Alexander R. W., Griendling K. K., Runge M. S. and Bernstein K. E. (1991) Isolation of a cDNA encoding the vascular type-1 angiotensin II receptor. Nature 351, 233-236

25. Natarajan R., Gonzales N., Hornsby P. J. and Nadler J. (1992) Mechanism of angiotensin II-induced proliferation in bovine adrenocortical cells. Endocrinology 131, 11741180

26. Ohnishi J., Ishido M., Shibata T., Inagami T., Murakami K. and MIYAZAKI H. (1992) The rat angiotensin II $\mathrm{AT}_{1 A}$ receptor couples with three different signal transduction pathways. Biochem. Biophys. Res. Commun. 186, 1094-1101

27. PEACH M. J. (1977) Renin-angiotensin system: biochemistry and mechanisms of actions. Phys. Rev. 57, 313-370

28. Powell J. S., Clozel J. P., Muller R. K. M., Kuhn H., Hefti F., Hosang M. and Baumgartner H. R. (1989) Inhibitors of angiotensin-converting enzyme prevent myointimal proliferation after vascular injury. Science 245 , 186188

29. Rosen L. B., Ginty D. D., Weber M. J. and Greenberg M. E. (1994) Membrane depolarization and calcium influx stimulate MEK and MAP kinase via activation of Ras. Neuron 12, 1207-1221

30. Rosen L. B. and Greenberg M. E. (1996) Stimulation of growth factor receptor signal transduction by activation of voltage-sensitive calcium channels. Proc. Natl. Acad. Sci. USA 93, 1113-1118

31. Sadoshima J. and Izumo S. (1993) Molecular characterization of angiotensin II-induced hypertrophy of cardiac myocytes and hyperplasia of cardiac fibroblasts. Circ. Res. 73, 413-423

32. Sasakı K., Yamano Y., Bardhan S., Iwai N., Murray J.,
Hasegawa M., Matsuda Y. and Inagami T. (1991) Cloning and expression of a complementary DNA encoding a bovine adrenal angiotensin II type-1 receptor. Nature 351, 230-233

33. Schorb W., Peeler T. C., Madigan N. N., Conrad K. M. and BAKER K. M. (1994) Angiotensin II-induced protein tyrosine phosphorylation in neonatal rat cardiac fibroblasts. J. Biol. Chem. 269, 19626-19632

34. Seuwen K., Magnaldo I. and Pouyssegur J. (1988) Serotonin stimulates DNA synthesis in fibroblasts acting through $5-\mathrm{HT}_{1 \mathrm{~B}}$ receptors coupled to a Gi-protein. Nature 335, 254 256

35. Shibata T., Suzuki C., Ohnishi J., Murakami K. and MIYAZAKI H. (1996) Identification of regions in the human angiotensin $\mathrm{II}$ receptor type 1 responsible for $\mathrm{Gi}$ and $\mathrm{Gq}$ coupling by mutagenesis study. Biochem. Biophys. Commun. 218, 383-389

36. Stachowiak M. K., Jiang H. K., Poisner A. M. and TUOMinen R. K. (1990) Short and long term regulation of catecholamine biosynthetic enzymes by angiotensin in cultured adrenal medullary cells. J. Biol. Chem. 265, 46944702

37. Takuwa N., Takuwa Y., Yanagisawa M., Yamashita K. and MASAKI T. (1989) A novel vasoactive peptide endothelin stimulates mitogenesis through inositol lipid turnover in Swiss 3 T3 fibroblasts. J. Biol. Chem. 264, 7856-7861

38. Tanaka M., Ohnishi J., Ozawa Y., Sugimoto M., Usuk S., Naruse M., Murakami K. and MiYazaKi H. (1995) Characterization of angiotensin II receptor type 2 during differentiation and apoptosis of rat ovarian cultured granulosa cells. Biochem. Biophys. Res. Commun. 207, 593-598

39. Tigyi G., Fischer D. J., Sebok A., Marshall F., Dyer D. L. and MLLEDI R. (1996) Lysophosphatidic acid-induced neurite retraction in $\mathrm{PC} 12$ cells: neurite-protective effects of cyclic AMP signaling. J. Neurochem. 66, 549-558

40. van Biesen T., Hawes B. E., Luttrell D. K., Krueger K. M., Touhara K., Porfiri E., Sakaue M., Luttrell L. M. and LEFKOwITZ R. J. (1995) Receptor-tyrosine-kinaseand $\mathrm{G}_{\beta \gamma}$ mediated MAP kinase activation by a common signaling pathway. Nature 376, 781-784

41. Yamada T., Horiuchi M. and Dzau V. J. (1996) The novel angiotensin II type 2 receptor mediates programmed cell death. Proc. Natl. Acad. Sci. USA 93, 156-160

42. Yamazaki T., Komuro Y., Kudoh S., Zou Y., Shiojima I., Mizuno T., Takano H., Hiroi Y., Ueki K. and Tobe K. (1995) Mechanical stress activates protein kinase cascade of phosphorylation in neonatal rat cardiac myocytes. J. Clin. Invest. 96, 438-446 